\title{
Erratum to: Global Perspectives on Same-Sex Marriage
}

\section{Bronwyn Winter}

Maxime Forest

Réjane Sénac

Editors

(C) The Editor(s) (if applicable) and The Author(s) 2018

B. Winter et al. (eds.), Global Perspectives on Same-Sex Marriage, Global Queer Politics, https://doi.org/10.1007/978-3-319-62764-9_1

DOI 10.1007/978-3-319-62764-9_12

The book was inadvertently published with an incorrect affiliation for Book Editor "Maxime Forest and Réjane Sénac". The correct affiliation is given below:

Maxime Forest

Sciences Po - OFCE

Center for Political Research CEVIPOF

Paris, France

Réjane Sénac

Sciences Po - CNRS

Center for Political Research CEVIPOF

Paris, France

The updated original online version of this book can be found at DOI 10.1007/978-3-319-62764-9

(C) The Author(s) 2018

B. Winter et al. (eds.), Global Perspectives on Same-Sex Marriage, Global Queer Politics, https://doi.org/10.1007/978-3-319-62764-9_12 